Eurasian Journal of Business and Economics, 14(28), 17-35, (2021).

\title{
Nature and Extent of International Diversification: Empirical Evidence from India
}

\author{
Aparna BHATIA*, Meenu KHURANA**
}

Received: April 26, 2021. Revised: November 05, 2021. Accepted: November 11, 2021.

\begin{abstract}
The paper aims to measure the extent of international diversification achieved by Indian companies in the recent time period. The study also investigates the nature of international diversification of companies during their transition beyond national boundaries. This evaluation of the firm's nature and extent of internationalization is further extended to cover the period of COVID-19 as well. The Jacquemin and Berry Entropy Approach (1979) is applied to operationalize the firm's international diversification. It facilitates the measurement of both inter-region and intra-region diversification. World Bank Geographical Region Classification Framework (2018) has been used to facilitate the applicability of the approach applied. Results indicate that Indian companies were inclined to grow beyond their home territories. However, the extent of international diversification is low as 'Internationally Low Diversification (ILD)' reveals to be the most popular strategy amongst Indian companies. Nature depicts a preference for relatedness than unrelatedness for overseas expansion as firms prefer intra-region expansion as compared to moving inter-region. Stagnation and halt are witnessed in the global expansion of companies in the period of the pandemic. The present study is novel as it comprehensively evaluates the international growth strategies preferred by Indian companies in the pre-pandemic and the pandemic period.
\end{abstract}

Keywords: International Diversification, Nature, Extent, Jacquemin and Berry Entropy Approach, COVID-19

JEL Classification Codes : B41, F21, F23, L19

UDC : 339.5

DOI : https://doi.org/10.17015/ejbe.2021.028.02.

\footnotetext{
* Assistant Professor, University School of Financial Studies, Guru Nanak Dev University, India, Email: aparnamohindru@yahoo.co.in

${ }^{* *}$ Research Scholar, University School of Financial Studies, Guru Nanak Dev University, India, Email: khurana meenu@yahoo.com
}

Copyright @, 2021 Ala-Too International University. 


\section{Introduction}

International Diversification is defined as the expansion of a firm outside the border of the home country into different geographical regions or countries (Hitt et al., 1997; Capar \& Kotabe, 2003). Here, firms look for investment opportunities abroad (Capar \& Kotabe, 2003; Brock et al., 2006). Globalization and liberalization of economies have boosted this practice of geographical diversification, thus stimulating the companies to consider the undiscovered boundaries. The strategy of International Diversification is advantageous to the growing companies in several ways. First of all, it helps companies to defeat the uncertainties associated with domestic policies and the political and macroeconomic environment of the native country (Miller, 1994). It also enables a firm to exploit the advantages of imperfections present in the capital, labor, and resource market of global regions (Cohen, 1972; Sambharya, 1995; Hitt et al., 1997; Lu \& Beamish, 2004) and hence allows firms to overcome the disadvantages of the weak institutional environment at the home front (Li \& Qian, 2005; Gaur \& Delios, 2015). The strategy many a time also provides an opportunity to gain access to abundant resources, cheap land, and low-cost labor outside the home country (Tallman \& Li, 1996; Atlaf \& Shah, 2016). It also creates ownership advantages abroad (Cohen, 1972; Sambharya, 1995; Hitt et al., 1997; Gokmen \& Temiz, 2013). The transfer of ownership advantages across multiple markets produces a synergistic effect (Ozturk \& Ibrahim, 2017). Transfer of a firm's resources into heterogeneous regions or countries is just like putting several eggs into multiple baskets. This leads to the reduction of risk and enhances stability in the earnings of the firm (Miller \& Pras, 1980; Sambharya, 1995; Abdullah, 2015). This also gives the added advantage of the complementarity of resources (Abdullah, 2015). Thus, firms tend to realize the economies of scale and scope (Azam, 2010; Wiersema \& Bowen, 2011; Ozturk \& Ibrahim, 2017). The cascading effect of geographical dispersal results in the maximization of the wealth of shareholders due to the least fluctuations in the firm's return on account of a diversified portfolio (Buhner, 1987). In a nutshell, international diversification is a supreme strategy of sustained growth.

But on the pessimistic side, besides these benefits, firms also face the costs involved in international market operations. The establishment of operations abroad initially results in costs related to liabilities of newness and foreignness (Lu \& Beamish, 2004; Karthik et al., 2015). Differences in trade policies, government regulations, culture, and economic environment across countries at times make the coordination difficult (Hitt et al., 1997). The cost of distributing the goods and managing the geographically dispersed operations also increases (Hitt et al., 1997). There are disadvantages related to information asymmetries and communication barriers (Abdullah, 2015). Underestimation or wrong estimation of consumer tastes, preferences, availability of resources, and level of competition in host countries can also be costly to the investing firm (Tihanyi et al., 2000). The presence of diverse institutional and cultural factors also hinders the movement of ownership advantages beyond the home 
country (Kogut, 1985; Geringer et al., 1989). Firms also face other costs related to recruiting the employees, establishing strong management systems and business networks in host countries (Singla \& George, 2013; Karthik et al., 2015). Choice of the channel of international entry also affects the associated cost (Hunger \& Wheelen, 2013). Thus, International diversification definitely adds to the complexity of business operations (Capar \& Kotabe, 2003).

But in spite of the convolutions involved, Internationalization is increasingly becoming a favored strategy of growth among companies, especially from emerging economies as emerging economies are greatly involved in expanding their business overseas (Onose and Aras, 2021). UNCTAD (2018) evidenced that emerging economies of Asia including our native land, India, accounted for one-fourth of the total world's outflows. In just a few decades, there is almost a three-fold increase in the amount of overseas direct investment of India; from USD2,985 million in 2005 to USD7,572 million in 2015, and lately it stood at USD11,037 million in 2018 (UNCTAD, 2018). India has risen 10 places higher in the world export ranking since 2005 and moved to 19th position in the year 2015. Among BRICS nations, India recorded the highest number of finalized international deals (UNCTAD, 2010). Even outbound merger and acquisition deals by Indian companies increased from USD.7 billion in 2000-01 to USD15 billion in 2006, reaching the highest of USD29.1 billion in 2009-10. Indian companies have also been entering into several important international strategic alliances like Mahindra \& Mahindra collaborated with US-based Ford Motor Company in September 2017, and Infosys entered into a joint venture with Japanbased Hitachi, Panasonic, and Pasona corporation in December 2018 to strategically increase their presence in foreign countries. This growing significance of Indian companies in the world market is definitely indicative of her exigent presence in the global scenario. It is observed that prolific literature that advocates the importance of product diversification since decades is available as Rumelt (1982), Palepu (1985), Bosworth et al. (1997), Raman (2002), Bhatia and Chander (2007), Chakrabarti et al. (2007), and Bhatia and Thakur (2016), etc. But there is a privation of research work accessible on international diversification. In contemporary times, International Diversification too is much in vogue. Hence, it is desirable to study the level and degree to which Indian firms are following the strategy of International Diversification and creating a new market niche for themselves. Thus, the current paper aims to analyze both the extent as well as nature of international diversification undertaken by Indian firms and gauge their inclination towards entering global markets. However, with the outbreak of the COVID-19 pandemic in the year 2019, it became difficult for companies to pursue the strategy of international diversification. Several confining measures as lockdowns and border closures restricted the movements and transitions of companies. Therefore, further assessment is made in the current study to examine the internationalization strategies of companies during the period of the pandemic.

The paper is structured as follows. The first section is the introduction to the topic of International Diversification and delineates its importance with respect to India. The 
second section presents the review of the literature on the nature and extent of the firm's international diversification and identifies the research gap. The third section explains the research methodology. In the fourth section, the results of the study are presented and analyzed. The fifth section discusses the results and presents theoretical implications. The study is finally concluded in section six with possible future directions of research.

\section{Review of Literature and Research Gap}

A review of extant literature imbues that there is no axiomatic method to measure the degree of international diversification. It is quite onerous to holistically capture the international transitions of different corporates around the whole world. Initially, researchers applied certain simple and preliminary measures of international diversification; the ratio of Foreign Sales to Total Sales being the most popular one (Rugman, 1976; Geringer et al., 1989; Sullivan, 1994; Sambharya, 1995; UNCTAD, 1995; Tallman \& Li, 1996; letto-Gillies, 1998; Tihanyi et al., 2000; Capar \& Kotabe, 2003; Chan-Olmsted \& Chang, 2003; Li \& Qian, 2005; Brock et al., 2006; Chari et al., 2007; Genthon, 2008; Gaur \& Kumar, 2009; Singla \& George, 2013; Gaur \& Delios, 2015; Atlaf \& Shah, 2016). Actually, the data related to the firm's foreign sales are easily available and accessible than other proxies of international diversification thus leading to ease in application of this measure. But this measure suffers from the problem of double counting as the amount of foreign sales includes the resale of intermediate goods (Tallman \& Li, 1996). Thereafter other similar formulations came into practice as Foreign Assets to Total Assets (Sullivan, 1994; Sambharya, 1995; UNCTAD, 1995; letto-Gillies, 1998; Li \& Qian, 2005; Singla \& George, 2013; Gaur \& Delios, 2015; Karthik et al., 2015), Foreign Employees to Total Employees (UNCTAD, 1995; letto-Gillies, 1998; Li \& Qian, 2005), Firm's overseas subsidiaries to total subsidiaries (Sullivan, 1994; Singla \& George, 2013), Total exports to total sales (Miller \& Pras, 1980; Geringer et al., 2000); and Number of foreign countries in which the company has affiliated to the total number of foreign countries in which potentially the company could have located subsidiaries (letto-Gillies, 1998; ChanOlmsted \& Chang, 2003). But these ratios are insufficient to capture the complete degree of internationalization as these classify the world only in two areas- the home and the foreign and fail to identify the international presence of firms across countries (Cohen, 1972; letto-Gillies, 1998). To explicate the gap, as per this approach firms having a similar ratio of foreign activities to total activities get the same degree of International Diversification though they operate in a different number of countries. Therefore, international count measures that capture the international presence of firms in different countries were proposed as, firm's number of overseas subsidiaries (Sambharya, 1995; Lu \& Beamish, 2004), and a number of foreign countries in which the firm has subsidiaries (Cohen, 1972; Rugman, 1976). However, these above-mentioned, ratio-based, and count-based measures fail to describe the nature/direction of a firm's international diversification i.e., relatedness/unrelatedness involved in international diversification. Though an 
effort is visible in the work of Chan-Olmsted and Chang (2003), Van Kranenburg et al. (2004), and Chadha and Berrill (2016) to measure the relatedness/unrelatedness involved in international diversification based on count measures but these could not capture the amount of foreign operations/investment in foreign subsidiaries or countries rightly called the breadth of international diversification. Therefore, in order to capture both the breadth and scope of firm's international operations, composite indices that aggregate the ratio, based measures with the count measures were proposed (Sullivan, 1994; letto-Gillies, 1998; Tihanyi et al., 2000; Chari et al., 2007; Singla \& George, 2013). But composite indexes suffer from measurement problems while integrating the ratio, based measures with the count, based measures. Hence, scholars considered Continuous Measures for capturing both the extent and nature of a firm's international diversification. Buhner (1987) applied Herfindahl Index to calculate the dispersion of a firm's sales across varied global market regions. The same measure was used by Van Kranenburg et al. (2004). But Herfindahl Index fails to decompose the nature of diversification into related and unrelated (Jacquemin \& Berry, 1979). Therefore, one of the most robust measures proposed is the Jacquemin and Berry entropy Approach (1979). It has the ability to decompose into various additive elements i.e., relatedness and unrelatedness (Ceptureanu et al., 2017). Hoskisson et al. (1993) even provide strong support for the reliability and validity of entropy measures. Also, as per the resolute belief of some researchers, entropy measure has more explanatory power in comparison to other continuous measures (Chatterjee \& Blocher, 1992). Thus, after the captious study of literature, it is unraveled that the entropy approach is preferable to simple measures on the basis of theoretical as well as empirical grounds.

Perhaps because of lack of consensus on the measurement of International Diversification (Sambharya, 1995), only a handful of studies are available that exclusively focus on measuring the extent of International Diversification of companies and establishing the nature of diversification. Authors first try to either trace or devise a methodology of measuring International Diversification and then apply the same to a defined sample of companies. Sullivan (1994) developed the Degree of Internationalization Scale (DOIINTS) and then ranked 74 American manufacturing companies based on their extent of diversification. Following suit, UNCTAD (1995) introduced a Transnationality Index by using ratio-based measures and compared developed countries with developing ones and found the former group to be more diversified than the latter one. letto-Gillies (1998) made modifications to this measure and developed a new index namely the Transnational Activity Spread Index that combined ratio-based measures with the count-based measures and found Transnational Corporations based in small countries to be more diversified than those in larger ones. Szymura-Tyc (2013) too constructed an Index of Internationalization by clubbing the inward and outward forms of international diversification and measured the degree of International Diversification of 274 firms based in Poland. Stephan (2002) measured the diversification level of 46 Multinational Corporations and found German-based corporations taking the lead in 
internationalization followed by Europe, the USA, and Japan. Chan-Olmsted and Chang (2003) evaluated just 7 global media conglomerates and ranked them. A few of these companies followed unrelated diversification while others preferred relatedness. Van Kranenburg et al. (2004) found Australian and European companies to be more diversified than those in North America. Also, low levels of strategies of diversification were followed with an intention to go in unrelated areas. Following the herd, Chadha and Berrill (2016) on a sample of 225 Japanese firms revealed transregional strategy as the most preferred one over the years from 1998 and 2013.

Anxiously negligible work is done with reference to emerging and developing economies. With specific reference to India, an effort is seen in the work of Gaur and Kumar (2009), Singla and George (2013), Gaur and Delios (2015), Karthik et al. (2015), and Atlaf and Shah (2016). But the focus of these studies is on analyzing the moderating role of business group affiliation or ownership structure or product diversification in the relationship between international diversification and firm performance, though Gaur and Kumar (2009) indicated a low degree of international diversification of 240 Indian manufacturing firms over the time period ranging from 1997 to 2011 while studying the relationship between international diversification and performance. Studies as Kumar (2007), Pradhan (2008), Athukorala (2009), Export Import Bank of India (2014), Das (2015), Athukorala and Veeramani (2017), Export Import Bank of India (2017), Pradhan (2017), and Khan and Faisal (2018) take up country-level analysis rather than corporate level as they use the data of India's Foreign Direct Investment Outflows.

To conclude, while reviewing the available studies, a few evident gaps are identified. First, only a handful of studies are available on the measurement of International Diversification. In fact, more focus is on proposing a measure rather than the calculation of the extent of international diversification of firms across the globe. Secondly, even when international diversification is measured, the majority of the studies use only preliminary measures for calculating International Diversification. As a result, the broader preview of the strategy of International Diversification that not only measures the degree of diversification but also its type and nature is not available. Additionally, generalization is impaired as most of the studies are based on small sample sizes. Thirdly, it is seen that majority of the work is done in developed countries. Emerging countries have ample scope and intention of growth and attention. Fourthly, no empirical literature at the micro-level exists with respect to the evaluation of internationalization strategies of companies during the period of COVID-19. Thus, the current study makes a humble effort to bridge the gap in the existing literature. An attempt is made to calculate the extent of International Diversification of companies in an emerging economy, India. Also, the nature of the International Diversification of Indian companies is evaluated by using a vigorous methodology framework namely Jacquemin and Berry Entropy Approach (1979). 


\section{Database and Research Methodology}

Business Today (BT), the leading business magazine, annually publishes the list of the most valuable companies of India. An effective sample of 429 companies is derived from the list of BT 500 most valuable companies published on 17 December 2017. The study covers the period of nine years ranging from 2009-10 to 2017-18. As a huge amount of initial cost is incurred by companies to establish operations abroad (Ozturk and Anil, 2017), growth projects are taken up by companies intermittently (Stonehouse and Snowdon, 2007). Hence studying a firm's international diversification across all nine years would not be desirable and even relevant. So, the total time period is divided into three equidistant points of time as 2009-10, 201314, and 2017-18 to comprehend the extent of international diversification undertaken by companies over nine years. Since the methodology applied requires, data relating to the firm's number of foreign subsidiaries in each country of the world, the same is collected manually from published Annual Reports of the companies. Both the collection as well as the calculation of values therefrom was a herculean task.

Additionally, in order to study the internationalization strategies of companies during the occurrence of the COVID-19 pandemic, another sample from NIFTY 50 companies has been taken. After eliminating Government-owned companies, and banking and non-banking financial institutions, an effective sample of 28 companies are considered for analysis. 2019-20 is taken as the pandemic period and compared with 2017-18, taken as a pre-pandemic period.

\subsection{Measure of International Diversification}

The entropy measure suggested by Jacquemin and Berry (1979) has been applied to capture the extent of international diversification. This measure takes into account three elements of a firm's diversity of international operations: the number of international markets in which the firm operates; dispersion of international operations across the international markets; the degree of relatedness among various international markets. International Diversification has been calculated through the entropy measure of Total International Diversification (TD), InterRegional Diversification, and Intra-Regional diversification of each firm. Total International Diversification is the sum of Inter-Regional Diversification and IntraRegional Diversification. It is formulated as follows:

$$
I D=\sum_{i=1}^{n}\left(P i * \frac{\ln 1}{P i}\right)
$$

Where, ID equals Total International Diversification; $\mathrm{n}$ is defined as a number of foreign countries in which the firm has subsidiaries and Pi means the proportion of firm's subsidiaries in the ith foreign country to the firm's total foreign subsidiaries. Inter-regional diversification (Unrelated International Diversification) captures the dispersion of the firm's subsidiaries across different geographical regions. It can be calculated as follows 


$$
\text { INTER }=\sum_{j=1}^{m}(P j * \ln / P j)
$$

Where, $m$ is equal to the number of regions in which the firm has subsidiaries and $\mathrm{Pj}$ is defined as the proportion of the firm's foreign subsidiaries in the jth region to the firm's total foreign subsidiaries. Intra-Regional Diversification (Related International Diversification) measures the dispersion of the firm's subsidiaries across similar countries within the region. (Vachani, 1991; Qian et al., 2010). It is calculated as follows:

$$
\operatorname{INTRA}=\sum_{j=1}^{m}(\operatorname{INTRA} j * P j)
$$

Where:

$$
\operatorname{INTRA} j=\sum_{I=j}(P j i * \ln 1 / P j i)
$$

Here, $m$ is the number of regions in which the firm has foreign subsidiaries; $\mathrm{Pj}$ is defined as the proportion of the firm's foreign subsidiaries in the jth region to the firm's total foreign subsidiaries and Pij equals the proportion of the firm's subsidiaries in the ith foreign country to the firm's total foreign subsidiaries in the jth region.

In order to measure International Diversification, the world needs to be classified into various markets or regions, or countries. Some researchers have considered the economic and political conditions, cultural boundaries, and external restrictions for classifying the world into heterogeneous regions (Miller \& Pras, 1980; Kim et al., 1993; Sambharya, 1995; Hitt et al., 1997; Goerzen \& Beamish, 2003). Chan-Olmsted and Chang (2003) adopted the Economic Growth Regional Classification framework based on the considerations of cultural, economic, and physical geographic divisions. Van Kranenburg et al. (2004) followed the Eurostat/European Union (2003) classification framework. However, Li and Qian (2005) followed the Geographical Region Classification Framework suggested by World Bank. According to Chrisman et al. (1988), a classification system should be collectively exhaustive and stable. Geography Based Classification system possessed the above attributes than other classification systems as it incorporates all the countries of the world and with the change in time geography, the based classification does not change. Therefore, the current study uses the World Bank Geographical Region Classification Framework (2018) used by Li and Qian (2005). This classifies the world into seven geographical regions, East Asia and Pacific, Europe and Central Asia, Latin America and the Caribbean, the Middle East and North Africa, North America, South Asia, and SubSaharan Africa.

As the entropy approach requires the data related to the firm's International Diversification broken down by regions or countries, most researchers relied on foreign revenue which describes the firm's foreign operations. As opined by Rugman (1976), the true picture of a firm's international diversification is fully reflected by its foreign investment and not by its foreign operations. Following Miller and Pras (1980), Sambharya (1995), and Qian et al. (2010), the present study has considered 
the firm's number of foreign subsidiaries in each country as a firm's foreign investment. In order to get insight into the international diversification strategies of the firm, the study pursues a two-dimensional categorical framework adopted by Vachani (1991) and Van Kranenburg et al. (2004). This classifies the firms into four international diversification strategies based on high and low levels of both interregional and intra-regional diversification. These high and low levels are determined using the mean as a cutoff value. Firms with entropy index greater than or equal to mean value are categorized under the high diversification category whereas firms with entropy value less than mean value are categorized under the low diversification category. As per the level of intra-regional and inter-regional diversification, four international diversification strategies are developed as shown in Table 1:

\section{Table 1. Two-Dimensional Categorical Framework}

\begin{tabular}{lcc}
\hline Intra-Region International & \multicolumn{2}{c}{ Inter-Region International Diversification } \\
\cline { 2 - 3 } Diversification & Low & High \\
\hline \multirow{2}{*}{ Low } & Internationally Low & Internationally Diffused \\
& Diversified (ILD) & Diversified (IDD) \\
\hline \multirow{2}{*}{ High } & Internationally Focused & Internationally High \\
& Diversified (IFD) & Diversified (IHD) \\
\hline
\end{tabular}

\section{Results and Analysis}

\subsection{Nature and Extent of International Diversification}

This section deals with an analysis of the nature and extent of international diversification of Indian companies. Table 2 shows the number and percentage of companies in each category/ strategy over three different points of time i.e., 200910, 2013-14, and 2017-18, covering the total period of nine years i.e., 2009 to 2018. During the year 2009-10, out of 429 companies, 219 (51\%) companies were in the category of IND whereas 210 (49\%) companies followed the strategy of ID. Among 210 internationally diversified companies, 70 (33\%) companies are Internationally Low Diversifiers, 22 (11\%) are Internationally Focused Diversifiers, and 57 (27\%) companies are Internationally Diffused Diversifiers whereas 61 (29\%) of the companies are placed in the category of Internationally High Diversifiers. Thus, ILD is the most favored strategy amongst Indian companies followed by the other extreme of IHD. IDD is the third preferred strategy with IFD being the least favored one. In comparison to Internationally Diversifiers, Internationally Non-Diversifiers are more at this point in time. This is the time when major relaxations in Indian overseas direct investment policy had been made in the recent past years only i.e., within 2000 2008. 
Table 2. International Diversification Strategies of Indian Companies

\begin{tabular}{lcccccc}
\hline \multirow{2}{*}{ Categories } & \multicolumn{2}{c}{$\mathbf{2 0 0 9 - 1 0}$} & $\mathbf{2 0 1 3 - 1 4}$ & \multicolumn{2}{c}{$\mathbf{2 0 1 7 - 1 8}$} \\
\cline { 2 - 7 } & No. & $\mathbf{\%}$ & No. & $\mathbf{\%}$ & No. & $\%$ \\
\hline A. Internationally Non- Diversifier (IND) & 219 & 51 & 197 & 46 & 180 & 42 \\
\hline B. Internationally Diversifier (ID) & 210 & 49 & 232 & 54 & 249 & 58 \\
\hline TOTAL (A+B) & 429 & 100 & 429 & 100 & 429 & 100 \\
\hline I. Internationally Low Diversifier (ILD) & 70 & 33 & 87 & 38 & 88 & 35 \\
\hline II. Internationally Focused Diversifier (IFD) & 22 & 11 & 26 & 11 & 34 & 14 \\
\hline III. Internationally Diffused Diversifier (IDD) & 57 & 27 & 51 & 22 & 54 & 22 \\
\hline IV. Internationally High Diversifier (IHD) & 61 & 29 & 68 & 29 & 73 & 29 \\
\hline TOTAL (I+II+III+IV) & 210 & 100 & 232 & 100 & 249 & 100 \\
\hline Source: Author's calutions & & & & & &
\end{tabular}

Source: Author's calculations

It seems that Indian companies had just initialized to establish their operations abroad as a higher proportion of companies are seen in the category of Internationally Non-Diversifiers at this point in time. Among the Internationally diversified category also, preference for the ILD category highlights that the extent of international diversification is low, though some firms have shown greater enthusiasm and have diversified intensely both intra-regionally as well as interregionally making IHD the second popular strategy of horizontal growth. The introduction of the FEMA Act in 2000 and the liberalization of outward FDI policy seem to be the stimulants behind the preference for extreme diversification. Still, the global recession of 2008 limped the quantum of companies going in for international diversification in 2009-10.

In the year 2013-14, companies placed in the category of Internationally NonDiversified declined to 197 (46\%) and those in Internationally Diversified category rose to $232(54 \%)$, thus witnessing a rise of 8 percent in the internationally diversified firms. The preference of sub-categories of ID strategy remained the same as in 200910 with ILD as the most preferred strategy followed by IHD, then IDD, and last the IFD. There is a 5 percent rise in the ILD category with an exactly similar decrease in the IDD category. IFD and IHD remain constant in their extent even after a gap of five years. The year 2013-14 represents the post-recession period when Indian companies recovered themselves from the ill effects of the global financial crisis. But it appears that their capacity of taking a risk by operating business across multiple global regions was skeptically affected. This is reflected by a decrease in the proportion of IDD from 27 percent to 22 percent and a similar level of increase in the ILD category from 33 percent to 38 percent. The intra-region expansion was favored more than the inter-region growth, thus highlighting the passive behavior of diversification.

In the year 2017-18, a further decline is seen in the case of Internationally NonDiversifier from 46 percent to 42 percent, thus suggesting a preference of diversifying even more. However, there is no change in the proportions of IDD and 
IHD category relative to the previous time period i.e., 2013-14, showing pessimism towards higher strategies of growth. An effective change of 3 percent is seen both in ILD and IFD where former declined and latter increased, by the same proportion, thus again suggesting intra-region growth preference of companies. Sluggishness is witnessed in the geographical dispersion of Indian companies. In fact, at this point in time, the Indian economy witnessed certain macro disruptions; first, the sudden announcement of demonetization of Indian currency by the government in November 2016 caught the business houses unaware. Liquidity crunch gripped the economy and there was a shortage of funds for establishing operations abroad. Secondly, the hasty implementation of Goods and Service Tax in July 2017 created unrest amongst the commercial firms. The transition to the new and complex tax regime saw strong disinclination for the expansion of businesses. Thus, the presence of institutional voids in the home country-restricted opportunities for firms to enhance their potential beyond national boundaries.

During the overall period of 2009-10 to 2017-18, companies are seen favoring the International Diversification strategy as the number of Internationally NonDiversified (IND) companies decreased from 219 to 180 (i.e., 51\% to 42\%). However, Internationally Low Diversifier (ILD) remains to be the most favored strategy of international diversification followed by Internationally High Diversification (IHD). Thus, Indian companies prefer two extremes in diversifying; either they stick within a particular region, thus favoring 'relatedness' in their expansion or they simply expand both intra- as well inter-region, thus depicting preference towards 'unrelatedness'. But a noticeable finding is that the proportion of companies in the IHD category remains constant at 29 percent at all three points of time while ILD increases relatively. Indian businesses did not take a chance of fiddling with higher growth strategies involving a higher degree of risk. They rather receded in IDD strategy and went in more for IFD whenever they wanted to expand. Indian managers diversify with caution. They seem to analyze the economic-social-political conditions both nationally and internationally. Though IHD seems to be the second favored strategy of diversification, yet a halt in its proportion is suggestive of a very cautious temperament of Indian companies. The nature of international diversification suggests a preference for 'Relatedness' as against 'Unrelatedness' making the extent low. Overall, Indian firms still seem to be in the early stages of internationalization.

\subsection{Nature and Extent of International Diversification: Pre-Pandemic and Pandemic Period}

Table 3 presents the number and percentage of companies in each strategy of international diversification in the pre-pandemic period, i.e., 2017-18, and pandemic period i.e., 2019-20. It is observed from Table 3 that the percentage of companies favoring different strategies of internationalization in the pre-pandemic period and the pandemic period remained exactly the same except for one company that moved from ILD to IHD. This suggests that with the sudden occurrence of COVID-19, 
companies halted their moves across the globe and held on to their existing positions. They seemed to have either canceled or postponed their investment plans in the wake of the pandemic.

Table 3. International Diversification strategies of Indian Companies in the Pre-Pandemic and the Pandemic Period

\begin{tabular}{lcccc}
\hline \multirow{2}{*}{ Categories } & \multicolumn{2}{c}{$2017-18$} & \multicolumn{2}{c}{$2019-20$} \\
\cline { 2 - 5 } & No. & $\%$ & No. & $\%$ \\
\hline A. Internationally Non- Diversifier (IND) & 2 & 7 & 2 & 7 \\
\hline B. Internationally Diversifier (ID) & 26 & 93 & 26 & 93 \\
\hline TOTAL (A+B) & 28 & 100 & 28 & 100 \\
\hline I. Internationally Low Diversifier (ILD) & 8 & 31 & 7 & 27 \\
\hline II. Internationally Focused Diversifier (IFD) & 1 & 4 & 1 & 4 \\
\hline III. Internationally Diffused Diversifier (IDD) & 6 & 23 & 6 & 23 \\
\hline IV. Internationally High Diversifier (IHD) & 11 & 42 & 12 & 46 \\
\hline TOTAL (I+II+III+IV) & 26 & 100 & 26 & 100 \\
\hline Source: Author's calculations & & & &
\end{tabular}

\section{Discussion and Theoretical Implications}

The results of our study show a restricted extent of International Diversification akin to the previous studies with respect to India as Gaur and Kumar (2009) suggest a low level of growth. Our study begins in 2009, where Gaur and Kumar (2009) left. But still, not much change is witnessed in the growth strategy of Indian firms. It divulges that there is no significant change in India's institutional environment over all these years. The voids in the institutional setup of India impede the growth of the corporate sector (Khanna \& Palepu, 2010). The Indian economy has been ambushed many times by the political acts and statutes, making the economic environment inconducive for growth. So, though years have passed, yet the perception of Indian managers regarding the adoption of internationalization strategy has remained quite static. All the more the outbreak of COVID-19 made them more stationary and reluctant in considering new foreign direct investment proposals. In fact, a handshake is required between the corporate sector and the Government. The corporate sector should not feel ambuscaded, maybe by the sudden and abrupt introduction of reforms or modifications in the current economic systems. Concord between the two would serve fruitful for the boundless growth of the country as a whole. There is seen comparability of our findings with the strategies followed by developed countries as well as witnessed in the works of Capar and Kotabe (2003) and Szymura-Tyc (2013). Perhaps the strategy of International Diversification has picked up greater momentum in recent times even in the developed economies of the world.

Contrary to our findings, Chadha and Berrill (2016) found more preference for the transregional strategy of international diversification by Japanese firms depicting an 
inclination towards higher diversification. Even Van Kranenburg et al. (2004) advocated Unrelated international diversification strategy as the most favored strategy among companies based in Australia, Europe, and North America as against our findings. Firms from developed countries enjoy several advantages in terms of institutional support. This allows them to spread their wings unhesitatingly across unfamiliar regions as compared to firms based in developing countries. To emphasize once again, Government support and institutional forces fuel growth. The government should boost internationalization. Certain measures as lowering of export duty and introduction of export promotion schemes may be undertaken. Tariffs may further be reduced. Quotas may be relaxed. There should be further liberalization of trade and capital market. Moreover, in order to facilitate the international business of firms in such a pandemic situation, the government should provide complete digital infrastructure. In brief, government intervention should be fecund and motivating for commercial firms. Till then, generalization of results would remain pending.

\section{Conclusion, Limitations, and Future Scope}

The current paper is in fact the first of its kind to measure the nature and extent of international diversification of Indian firms in such a holistic manner, covering even the period of the pandemic. With the increase in momentum of globalization and liberalization, Indian companies have shown an inclination to grow beyond their home territories. But the extent of international diversification is low. Internationally Low Diversification (ILD) is more popular than other strategies of international diversification. However, preference for Internationally High Diversification (IHD) strategy, the other extreme, as the second most popular category suggests that Indian firms prefer to explore the unrelated areas as well. But a prominent finding where the proportion of companies remains constant in the IHD category at all three points of time arouses the inquisitiveness of the researchers and coaxes them to contemplate certain restrictive factors for growth. The results also suggest that the preference for growth is in the related areas as compared to the unrelated ones as the transition is towards the low categories as ILD and IFD categories rather than the higher strategies of International Diversification. Analysis of firms' internationalization in the pandemic era revealed that companies witnessed stagnation in their extent of internationalization as the pandemic restricted the transitions of companies across the globe.

Thus, the present paper opens vistas of international intentions of Indian companies. However, certain limitations of the present study provide substantial avenues for future research. As the study excludes the Financial and Government sectors from the sample, prospective studies may be undertaken to address the issue of analyzing the nature and extent of international diversification of companies in the financial and government sector as well. The current study covers the first three months of the occurrence of COVID-19 in the year 2019-20. The present study can be replicated for the year 2020-21 to gauge the internationalization moves of companies over a 
longer period of the pandemic. Also, the sample size can be increased for better generalization of results. Besides, an evaluation of determinants of international diversification should be made in order to unveil the factors affecting horizontal growth. An analysis of "institutional voids" and certain factors as government policies, incentives for outbound investment, financing of investments, the success rate in the overseas acquisitions, tax regimes/treaties, etc. is desirable. Nevertheless, the paper in its current form would definitely add value to the existing literature on international diversification and inspire the researchers to move on.

\section{Disclosure Statement}

No potential conflict of interest was reported by the authors.

\section{References}

Abdullah, H.H. (2015). Significance of studying product diversification, geographic diversification, and their interaction impacts for Malaysian companies: a literature review. Asian Social Science, 11(10), 238-250. https://doi.org/10.5539/ass.v11n10p238

Athukorala, P. C., \& Veeramani, C. (2017). Internationalization of Indian enterprises: Patterns, determinants, and policy issues. Asian Economic Papers, 16(1), 142-166. https://doi.org/10.1162/ASEP a 00496

Athukorala, P.C. (2009). Outward foreign direct investment from India. Asian Development Review, 26(2), 125-153. http://hdl.handle.net/11540/1674

Atlaf, N., \& Shah, F.A. (2016). Internationalization and firm performance of Indian firms: Does product diversity matter?. Pacific Science Review B: Humanities and Social Sciences, 1(2), 76 84. https://doi.org/10.1016/i.psrb.2016.05.002

Azam, M. (2010). Economic determinants of foreign direct investment in Armenia, Kyrgyz Republic and Turkmenistan: Theory and evidence. Eurasian Journal of Business and Economics, 3(6), 27-40. https://ejbe.org/EJBE2010Vol03No06p27AZAM.pdf

Bhatia, A., \& Chander, S. (2007). Diversification strategy and corporate performance in India (Unpublished Doctoral dissertation). Guru Nanak Dev University, Amritsar, Punjab, India.

Bhatia, A., \& Thakur, A. (2016). Diversification strategies of multi-national and domestic companies in India: A comparative evaluation in the dynamic environment. Management and Labour Studies, 41(3), 199-215. https://doi.org/10.1177\%2F0258042X16666578

Bosworth, D., Dawkins, P., Harris, M., \& Kells, S. (1997). Diversification and the performance of Australian enterprises. (Melbourne Institute Working Paper No. 28/97). Melbourne Institute of Applied Economic and Social Research. https://melbourneinstitute.unimelb.edu.au/downloads/working paper series/wp1997n28. pdf

Brock, D. M., Yaffe, T., \& Dembovsky, M. (2006). International diversification and performance: A study of global law firms. Journal of International Management, 12(4), 473 489. https://doi.org/10.1016/j.intman.2006.08.003

Buhner, R. (1987). Assessing international diversification of West German corporations. Strategic Management Journal, 8(1), 25-37. https://doi.org/10.1002/smj.4250080104 
Nature and Extent of International Diversification: Empirical Evidence from India

Capar, N., \& Kotabe, M. (2003). The relationship between international diversification and performance in service firms. Journal of International Business Studies, 34(4), 345-355. https://doi.org/10.1057/palgrave.jibs.8400036

Ceptureanu, S. I., Ceptureanu, E. G., \& Marin, I. (2017). Assessing the role of strategic choice on organizational performance by Jacquemin-Berry Entropy Index. Entropy, 19(9), 448. https://doi.org/10.3390/e19090448

Chadha, P., \& Berrill, J. (2016). An empirical investigation into the internationalization patterns of Japanese firms. Asia Pacific Business Review, 22(4), 595-611. https://doi.org/10.1080/13602381.2016.1168616

Chakrabarti, A., Singh, K., \& Mahmood, I. (2007). Diversification and performance: Evidence from East Asian firms. Strategic Management Journal, 28(2), 101-120. https://doi.org/10.1002/smj.572

Chan-Olmsted, S.M., \& Chang, B.H. (2003). Diversification strategy of global media conglomerates: Examining its patterns and determinants. The Journal of Media Economics, 16(4), 213-233. https://doi.org/10.1207/S15327736ME1604 1

Chari, M. D., Devaraj, S., \& David, P. (2007). International diversification and firm performance: Role of information technology investments. Journal of World Business, 42(2), 184-197. https://doi.org/10.1016/j.jwb.2007.02.004

Chatterjee, S., \& Blocher, J. D. (1992). Measurement of firm diversification: Is it robust?. Academy of Management Journal, 35(4), 874-888. https://doi.org/10.5465/ 256320

Chari, M. D., Devaraj, S., \& David, P. (2007). International diversification and firm performance: Role of information technology investments. Journal of World Business, 42(2), 184-197. https://doi.org/10.1016/i.jwb.2007.02.004

Chatterjee, S., \& Blocher, J. D. (1992). Measurement of firm diversification: Is it robust?. Academy of Management Journal, 35(4), 874-888. https://doi.org/10.5465/256320

Chrisman, J. J., Hofer, C. W., \& Boulton, W. B. (1988). Toward a system for classifying business strategies. Academy of Management Review, 13(3), 413-428. https://doi.org/10.2307/258089 Cohen, B. (1972). Foreign investment by US corporations as a way of reducing risk (Working Paper No. 151). Economic Growth Center, Yale University. https://elischolar.library.yale.edu/egcenter-discussion-paper-series/159

Das, K. C. (2015). Outward FDI by Indian manufacturing MNEs: Impacts and implications (ARTNeT Working Paper Series No. 148). Asia-Pacific Research and Training Network on Trade (ARTNeT), Bangkok. http://hdl.handle.net/10419/145384

Export Import Bank of India. (2014, May). Outward direct investment from India: Trends, objectives and policy perspectives (Occasional Paper No. 165). https://www.eximbankindia.in/research-papers

Export Import Bank of India. (2017, July). The internationalization of Indian firms through outbound foreign direct investment: Nature, determinants and developmental consequences (Occasional Paper No. 183). https://www.eximbankindia.in/research-papers

Gaur, A. S., \& Delios, A. (2015). International diversification of emerging market firms: The role of ownership structure and group affiliation. Management International Review, 55(2), 235253. https://doi.org/10.1007/s11575-015-0240-0 
Gaur, A. S., \& Kumar, V. (2009). International diversification, business group affiliation and firm performance: Empirical evidence from India. British Journal of Management, 20(2), 172-186. https://doi.org/10.1111/i.1467-8551.2007.00558.x

Genthon, C. (2008, September 25-26). International diversification, performance and offshoring: The case of the computer services industry. Paper presented at XVIII International RESER Conference "New horizons for the role and production of services", Stuttgart. https://halshs.archives-ouvertes.fr/docs/00/34/81/98/PDF/pub08033.pdf

Geringer, J. M., Tallman, S., \& Olsen, D. M. (2000). Product and international diversification among Japanese multinational firms. Strategic Management Journal, 21(1), 51-80. https://doi.org/10.1002/(SICI)1097-0266(200001)21:1\%3C51::AID-SMJ77\%3E3.0.CO;2-K

Geringer, J., Beamish, P. W., \& DaCosta, R. C. (1989). Diversification strategy and internationalization: Implications for MNE performance. Strategic Management Journal, 10(2), 109-119. http://dx.doi.org/10.1002/smj.4250100202

Goerzen, A., \& Beamish, P. W. (2003). Geographic scope and multinational enterprise performance. Strategic Management Journal, 24(13), 1289-1306. https://doi.org/10. $\underline{1002 / \mathrm{smj} .357}$

Gokmen, A., \& Temiz, D. (2013). Born global firms: A foreign trade related study on Turkey. Eurasian Journal of Business and Economics, 6(12), 129-142. https://www.ejbe.org/EJBE2013Vol06No12p129-GOKMEN-TEMIZ.pdf

Hitt, M. A., Hoskisson, R. E., \& Kim, H. (1997). International diversification: Effects on innovation and firm performance in product-diversified firms. Academy of Management Journal, 40(4), 767-798. https://doi.org/10.5465/256948

Hoskisson, R. E., Hitt, M. A., Johnson, R. A., \& Moesel, D. D. (1993). Construct validity of an objective (entropy) categorical measure of diversification strategy. Strategic Management Journal, 14(3), 215-235. https://doi.org/10.1002/smj. 4250140305

Hunger, J. D., \& Wheelen, T. L. (2013). Essentials of Strategic Management (New International Edition). London: Pearson Higher Ed.

letto-Gillies, G. (1998). Different conceptual frameworks for the assessment of the degree of internationalization: An empirical analysis of various indices for the top 100 transnational corporations. Transnational Corporations, 7(1), 17-40.

Jacquemin, A. P., \& Berry, C. H. (1979). Entropy measure of diversification and corporate growth. The Journal of Industrial Economics, 27(4), 359-369. https://doi.org/10.2307/2097958

Karthik, D., George, R., \& Singla, C. (2015). International diversification and firm performance: The contingent influence of product diversification (IIMA Working Paper WP2015-03-32). Indian Institute of Management Ahmedabad, Research and Publication Department. https://web.iima.ac.in/assets/snippets/workingpaperpdf/13042529052015-03-32.pdf

Khan, A. K., \& Faisal, S. M. (2018). Role and significance of FDI (outward) in Indian perspective an analysis: Post demonetization period. J Account Mark, 7(276), 2. https://doi.org/10.4172/2168-9601.1000276 
Nature and Extent of International Diversification: Empirical Evidence from India

Khanna, T., \& Palepu, K. G. (2010). Winning in emerging markets: A road map for strategy and execution. United States of America: Harvard Business Press. https://doi.org/10.1177/0974173920100316

Kim, W. C., Hwang, P., \& Burgers, W. P. (1993). Multinationals' diversification and the riskreturn trade-off. Strategic Management Journal, 14(4), 275-286. https://doi.org/10.1002/smj.4250140404

Kogut, B. (1985). Designing global strategies: Comparative and competitive value-added chains. Sloan Management Review (pre-1986), 26(4), 15. https://www.researchgate.net/publication/279888916 Designing Global Strategies Compa rative and Competitive Value-Added Chains

Kumar, A. (2007). Do the diversification choices of individual investors influence stock returns?. Journal of Financial Markets, 10(4), 362-390. https://doi.org/10.1016/i.finmar.2007.06.003

Li, L., \& Qian, G. (2005). Dimensions of international diversification: Their joint effects on firm performance. Journal of Global Marketing, 18(3-4), 7-35. https://doi.org/10.1300/J042v18n03 02

Lu, J. W., \& Beamish, P. W. (2004). International diversification and firm performance: The Scurve hypothesis. Academy of Management Journal, 47(4), 598-609. https://doi.org/10.2307/20159604

Miller, J. C., \& Pras, B. (1980). The effects of multinational and export diversification on the profit stability of US corporations. Southern Economic Journal, 46(3), 792-805. https://doi.org/10.2307/1057148

Miller, K. D. (1994). Diversification responses to environmental uncertainties (Purdue CIBER Working Paper No. 82). Purdue University. http://docs.lib.purdue.edu/cgi/viewcontent.cgi?article=1082\&context=ciberwp

Onose, O. L. ., \& Aras, O. N. (2021). Does the export-led growth hypothesis hold for services exports in emerging economies?. Eurasian Journal of Business and Economics, 14(27), 63-75. https://doi.org/10.17015/ejbe.2021.027.04

Ozturk, I., \& Ibrahim, A. (2017). The Interaction of firm performance with international geographic diversification and internal factors: A research on Borsa Istanbul companies. Journal of Strategic Research in Social Science, 3(1), 31-42.

Palepu, K. (1985). Diversification strategy, profit performance and the entropy measure. Strategic Management Journal, 6(3), 239-255. https://doi.org/10.1002/smj.4250060305

Pradhan, J. P. (2008). The evolution of Indian outward foreign direct investment: Changing trends and patterns. International Journal of Technology and Globalisation, 4(1), 70-86. https://doi.org/10.1504/IJTG.2008.016188

Pradhan, J. P. (2017). Emerging multinationals: A comparison of Chinese and Indian outward foreign direct investment. Institutions and Economies, 3(1), 113-148. https://mjes.um.edu.my/index.php/ijie/article/download/4779/2597 
Qian, G., Khoury, T. A., Peng, M. W., \& Qian, Z. (2010). The performance implications of intraand inter-regional geographic diversification. Strategic Management Journal, 31(9), 10181030. https://doi.org/10.1002/smj.855

Raman, R. (2002). Impact of diversification strategy on corporate financial performance (Unpublished Doctoral dissertation). HNB Gharwal University, India.

Rugman, A. M. (1976). Risk reduction by international diversification. Journal of International Business Studies, 7(2), 75-80. https://doi.org/10.1057/palgrave. jibs.8490702

Rumelt, R. P. (1982). Diversification strategy and profitability. Strategic Management Journal, 3(4), 359-369. https://doi.org/10.1002/smj.4250030407

Sambharya, R. B. (1995). The combined effect of international diversification and product diversification strategies on the performance of US-based multinational corporations. MIR: Management International Review, 35(3), 197-218.

Singla, C., \& George, R. (2013). Internationalization and performance: A contextual analysis of Indian firms. Journal of Business Research, 66(12), 2500-2506. https://doi.org/10.1016/j.jbusres.2013.05.041

Stephan, M. (2002). An analysis of the relationship between product diversification, geographical diversification and technological diversification (Discussion Paper 2-02). University of Hohenheim, Department of International Management. https://www.econbiz.de/archiv/s/uhoh/internationales management/analysis relationship diversification.pdf

Stonehouse, G., \& Snowdon, B. (2007). Competitive advantage revisited: Michael Porter on strategy and competitiveness. Journal of Management Inquiry, 16(3), 256-273. https://doi.org/10.1177\%2F1056492607306333

Sullivan, D. (1994). Measuring the degree of internationalization of a firm. Journal of International Business Studies, 25(2), 325-342. https://doi.org/10.1057/palgrave. jibs.8490203

Szymura-Tyc, M. (2013). Measuring the degree of firms' internationalization at their early stages of international commitment. Journal of Economics \& Management, 13, 101-118. http://yadda.icm.edu.pl/yadda/element/bwmeta1.element.desklight-61641873-1914-46acb9a2-7d1d531eb134/c/7 Szymura-Tyc Measuring the degree of firms.pdf

Tallman, S., \& Li, J. (1996). Effects of international diversity and product diversity on the performance of multinational firms. Academy of Management Journal, 39(1), 179-196. https://doi.org/10.2307/256635

Tihanyi, L., Ellstrand, A. E., Daily, C. M., \& Dalton, D. R. (2000). Composition of the top management team and firm international diversification. Journal of Management, 26(6), 1157-1177. https://doi.org/10.1016/S0149-2063(00)00076-3

UNCTAD. (1995). World investment report 1995: Transnational corporations and competitiveness. Geneva: United Nations. https://doi.org/10.18356/5106ab9e-en

UNCTAD. (2010). World investment report 2010: Investing in a low carbon economy. Geneva: United Nations. https://doi.org/10.18356/40d902ba-en 
UNCTAD. (2018). World investment report 2018: Investment and new industrial policies. Geneva: United Nations. https://doi.org/10.18356/ebb78749-en

Vachani, S. (1991). Distinguishing between related and unrelated international geographic diversification: A comprehensive measure of global diversification. Journal of International Business Studies, 22(2), 307-322. https://doi.org/10.1057/palgrave. jibs.8490305

Van Kranenburg, H., Hagedoorn, J., \& Pennings, J. (2004). Measurement of international and product diversification in the publishing industry. Journal of Media Economics, 17(2), 87-104. https://doi.org/10.1207/s15327736me1702 2

Wiersema, M. F., \& Bowen, H. P. (2011). The relationship between international diversification and firm performance: Why it remains a puzzle. Global Strategy Journal, 1(1-2), 152-170. https://doi.org/10.1002/gsi.5

World Bank (2018). World Bank Geographical Region Classification Framework https://datahelpdesk.worldbank.org/knowledgebase/articles/906519-world-bank-countryand-lending-groups 